\title{
Reconfigurations of Time: Reflections on the Exhibition, Arts of Resistance: Politics and the Past in Latin America, UBC Museum of Anthropology
}

\author{
Laura Osorio Sunnucks
}

\begin{abstract}
This article reflects on the exhibition Arts of Resistance: Politics and the Past in Latin America, showing how the project challenged common representations of Central and South American art and history by displaying local, often Indigenous, ways of managing cultural heritage, as well as some of the ways that ancestral knowledge and popular arts are used to document and resist political realities. Furthermore, it argues for the overt politicization of museological and exhibitionary perspectives using radical cosmopolitical theory. Through this framework, I argue for the political significance of the art forms included in the exhibition that champion local philosophies and positions in the face of various forms of marginalization.
\end{abstract}

Key words: museum archaeology, critical museology, decolonising methodologies, Indigenous art, local heritage management, political museology, radical cosmopolitics, Latin American archaeology

The role of anthropology and related institutions, such as museums, has been destabilized as a result of radical critiques of the discipline (Asad 1973; Hymes 1974; Fabian 1983; Clifford and Marcus 1986; Comaroff et al. 2009), alongside factors external to academia such as new socio-cultural and political group making, digital technologies and, pertinently in the case of this paper and the exhibition it reviews, the brokering of new power relationships by Indigenous Peoples. However, in spite of museological critiques showing that these institutions fail to address their Enlightenment-derived legitimating logics, the older paradigm remains dominant. While certain anthropology museums have undergone paradigmatic changes in response to Indigenous agency, and archaeological research is, in some cases, conducted by or in collaboration with Indigenous intellectuals/communities (in the case of Central and South America, see Gnecco and Rocabado 2010; Cojtí Ren 2015; McAnany 2016; Jansen and Pérez Jiménez 2017; Reyes Gómez 2017; Acuña Suárez and Miranda 2018), there are few international exhibitions that engage with the Indigenous politics of 'archaeological' material in museums. Meanwhile, it has been shown that archaeological and historical studies of pre-Hispanic cultures have been strongly affected by the socio-political history of the region, in terms of post-Independence nation-building programmes and state repression in the 1960s-1980s (Funari et al. 2009).

This paper reviews a recent exhibition curated by the author, Arts of Resistance: Politics and the Past in Latin America (Museum of Anthropology, University of British Columbia (hereafter MOA UBC) 2018). This exhibition displayed predominantly 'popular' and Indigenous art that invokes the region's pre-Columbian past and local or ancestral knowledge in the context of contemporary political realities. The project employed radical cosmopolitics (Ribeiro and Escobar 2006; Ribeiro 2014; de Sousa Santos 2014, 2018) as a framework through which to understand local heritage management and challenge the ways the Central and South American past is represented in anthropology and art museums. It also argues for the sociopolitical relevance of museum exhibitions based on marginalized cultures and Indigenous epistemologies, which can counter the cultural essentialism mobilized by many museum projects in their uncritical representation of early ethnographic and archaeological collections and classifications. 


\section{The Politics of Latin American Archaeology in the Museum}

The empiricist project of the seventeenth and eighteenth centuries, in which archaeological and anthropological collecting played an integral role, developed functionally and ideologically alongside European colonial expansion, extractive projects and race science. As such, the agendas employed to justify the importance of collecting are embedded in colonial projects that undermined, rather than supported, the early subjects of anthropological enquiry. In spite of the political biographies of the objects that make up museum collections, this material is traditionally represented in neutral terms that describe the specific cultures and geographical territories to which they (are thought to) pertain. The failure by ethnography museums to expose the relationship between these territories and their respective political jurisdictions has been well established, demonstrating that the cultural expressions they nurture do not correspond to continuous territorial, genealogical, historical or political affiliations but rather, expose the discontinuity and fragmentation in a singular global history that has been experienced unequally and variably (Shelton 1997: 34). Anthropological critiques have also looked to the binary subject/object episteme that extends throughout Western thought (Heidegger 1927 (2008); Husserl 1931 (1960)) to deconstruct the classifications and 'othering' that underpin the discipline (Bourdieu 1984; De Certeau 1986; Hymes 1974; Lyotard 1979). The condition of European society is predicated on the division between the 'self' - or our own culture - and a speculatively defined 'other' whose rationality has been cast doubt upon, and, by appropriating fragments of local knowledge and interpreting cultures through a seemingly neutral framework, museums have contributed to the creation of a 'paradigmatic knowledge', while seeming to be reluctant to relinquish any of the 'authority' this knowledge production system confers on them (Shelton 1997: 35). While ethnographic collections have received sustained critique and certain anthropology museums and museum projects have interrupted this paradigmatic knowledge (see, for example, Lyotard 1979; Shelton 1997, 2001, Ames 2003; Peers and Brown 2003; Estévez González 2004; Gonseth at al. 2005; Buntinx 2006; Cameron and Kenerdine 2007; Colwell-Chanthaphonh and Ferguson 2007; Knell et al. 2007; Macdonald and Basu 2007; Collison and Steedman 2011; Phillips 2011; Shelton 2013; Henríquez and de Santa Ana 2019; Snoep 2020); and, while community collaboration has been shown to be complicated (Pérez Ruiz 2008), and arguably research needs to focus more on which communities and who within them is given a voice by the institution (for example, Fouseki 2010; Shelton 2018), museums with archaeological collections continue, in many cases, to be de-politicized spaces which obfuscate the many and varied power imbalances they represent and, arguably, continue to perpetuate (see Reilly 2018; Janes and Sandell 2019; Hicks 2020; Procter 2020).

Paradigmatic knowledge has been exported through colonialism to the global south and has coupled with local political agendas to reinforce cultural and social marginalization. As Linda Tuhiwai Smith, of Ngati Awa and Ngati Porou, states (1999: 2), the '...collective memory of imperialism has been perpetuated through the ways in which knowledge about indigenous peoples was collected, classified and represented in various ways back to the West, and then through the eyes of the West, back to those who have been colonised'. Museums have become an emblem of the well-furnished state (Duncan 1991) and, for example, blockbuster archaeology exhibitions that showcase historic treasures, such as The Power of the Sun: The Gold of Colombia (Ethnographic Museum in Antwerp 1993), which later toured Belgium and the Netherlands, are sponsored by governments and are often facilitated by governmentally managed heritage institutions. Other more recent examples include EIDorado: Powerand Gold in Ancient Colombia (British Museum 2013), sponsored and organized in collaboration with the Museo del Oro in Colombia, a museum that belongs, like many other cultural institutions in Colombia, to the nation's Central Bank, and The Aztecs (Linden-Museum Stuttgart2019-2020), which was curated in conjunction with the National Museum van Wereldculturen Netherlands and the Instituto Nacional de Antropología e Historia in Mexico. Not only are these projects arguably in the hands of dominant, elite intellectual and governmental sectors of society in the global south, they have also been shown to be used in the manoeuvring of international diplomacy and politics (see Wallis 1994). They focus on magnificent and tidily historicized pre-Columbian societies (Shelton 2018: 125), rarely engaging in contemporary Indigenous 
politics. The decisions to exclude this aspect of cultural heritage are problematic and pertinent to Indigenous activism, which struggles against the image - built by early national and often racist projects - that indigeneity is a historicized state of being, un-evolving and apolitical (McEnroe 2012; Berger 2016). In the case of Mexico, to take an example, this process has its inception in colonial misunderstandings of contact era cultures (Jansen and Pérez Jiménez 2017). The subsequently racist colonial administration was eventually followed by a postrevolutionary national education project by José Vasconcelos, which conceived modern Mexicans as a 'Cosmic Race', a hybrid identity built on the strength of its pre-Columbian civilizations improved by European rationality (McEnroe 2012; Ward 2018). Across Latin America, projects such as these have mobilized historic images and ideas that reproduce and manipulate the past in the present and which continue to intersect with neoliberal projects to disenfranchise Indigenous People (Baud and Ypeij 2009).

Post-processual archaeological studies have rethought epistemologies of the past and material culture, deconstructing the empirical underpinnings and colonial legacy of the discipline, and questioning the scientific architecture that archaeological methods and theories rely on (Hodder 1985; 1987; Tilley 1990; Shanks and Tilley 1992; Hodder et al. 1995). David Lowenthal, in The Past is a Foreign Country (1985 [2015]: xvi), explored the ways that the past has been appropriated and manipulated in Europe and the United States since the nineteenth century and, although the book focuses neither on the histories of the global south nor on archaeology specifically, examples of the heterogenous relationships that human societies build with the past show that the Enlightenment-derived creation of the past as a distanced and untouched country or culture underlies the ways material heritage is managed now. More recent literature has acknowledged that the preservation and appropriation of the past, purposefully or otherwise, tell us more about the present than they do about the past. Archaeologies of the contemporary past have increasingly used traditional archaeological methods to supplement sociological, geographical and political analyses of the last half of the twentieth and early twenty-first centuries (Buchli and Lucas 2001; Graves-Brown et al. 2013; Ferris et al. 2014), and theoretical archaeology is now often made relevant to socio-material practices, acknowledging the inherent multi-temporality of these investigative contributions (Harrison and Breithoff 2017). Other recent scholarship in the field has demonstrated that, following a focus on contemporary society, certain scholars of the past can and do address issues in the present, such as capitalism, neoliberalism, inequality, climate change, food insecurity, racism, xenophobia and neocolonialism (Rosenzweig 2020). In museology, these theories have been explored by the late Fernando Estévez González. His exhibitions, such as El Pasado en el Presente (Museo de Antropología de Tenerife 2003) and Souvenir, Souvenir, La Colección de (los) Turistas (Museo de Antropología de Tenerife 2009), expose the relationships between contemporary tourism, which seeks to discover and consume pristine cultures without being conscious of the impact it has, and anthropological and archaeological collecting in the nineteenth century (Estévez González 2004; Culler and Estévez in Henríquez and de Santa Ana 2019: 39; Estévez González 2019). In this way, Estévez González argues, the past is reduced to fiction. Following Mikhail Bakhtin's literary theory (1981), museums serve as chronotopes (Isaac 2007; Binter 2019), in which objects from different times are gathered or juxtaposed, lending temporal causality to narratives about the past. Relevantly, many Indigenous and non-Indigenous Peoples in Meso and South America have ways of understanding, commemorating and representing time that differs radically from the linear historical totalizations reinforced by museum collections and exhibitionary projects (Gnecco and Hernández 2010; Jansen and Pérez Jiménez 2017). ${ }^{1}$

\section{Art and artefact}

Although many anthropologists of art have concluded that the divisions between Indigenous/ contemporary/popular and non-Western arts are no longer useful (see, for example, García Canclini 1990; Morphy 2007), one of the ways non-Western societies have arguably been othered by anthropology and its related institutions is in the designation of their material culture as artefacts rather than art, a classificatory system which is also reflected in the institutional divisions of their collections. This has been the case in spite of critiques that the use of Western aesthetic parameters that have their inception in Kantian thought to interpret historical 
creative material culture is incongruous (Power and Escobar 2012: 35). Susan Vogel writes in 1991 that the 'arts' of Africa (aside from Egypt), Oceania and the Americas have not been included in art institutions long enough for their presence to be accepted without question as art (Vogel 1991: 192). The exhibitions, Perspectives: Angles on African Art (Center for African Art 1987) and Art/Artifact (Center for African Art 1991), both curated by Vogel, challenged the traditional learned aesthetic judgement and appreciation of museum audiences, exploring the role the museum has played in creating and managing the knowledge and expectations of that audience. However, many institutions and exhibitions continue to reinforce the categories of art and ethnographic object, connoting form and contextual information respectively (Yoshida and Mack 1997; Macdonald and Basu 2007; Geismar 2015).

The exhibition Hispanic Art in the United States: Thirty Contemporary Painters and Sculptors (Museum of Fine Arts, Houston 1983-1987) sought to create representation in a fine art institution for 'Hispanic' artists in the United States. The exhibition was consciously non-sociological, aiming to elevate Hispanic art in public opinion by virtue of its formal and aesthetic values. The curators, John Beardsley and Jane Livingston, conceded that the political context of the works was relevant: '... of course we knew that, especially in this case art and social context are inseparable' (Beardsley and Livingston 1991: 108). However, the main criticism of this project was precisely its lack of political content, specifically the noninclusion of street murals: Ybarra-Frausto, for example, asserts that mural making in the barrio was an active, collaborative project that involved a range of community members, not just artists, and that Chicano art in the 1960s and 1970s encompassed a political as well as an aesthetic position (Ybarra-Frausto 1991: 140). In 2018, the Museum of San Diego and the Museo Jumex (Mexico) curated the 'contemporary art' exhibition, Memories of Underdevelopment (Museo Jumex 2018), which explored decolonial movements in Latin American art from 1960 to 1985. Among those represented was 'no objetalismo', the nonobject-based art movement championed by the Peruvian art critic Juan Acha in response to Brazilian artists such as Mário Pedrosa, Ferreira Gullar, Ana Bella Geiger, Lygia Pape, and Hélio Oiticica. These avant-garde artists eschewed the creation of art-objects whose meaning was constituted outside of their customary context, preferring to channel popular cultural consciousness through their works. However, this exhibition has been criticized for engaging in 'decoloniality' without establishing the specific definition of the term as it is employed in this exhibition. ${ }^{2}$ Furthermore, the lack of rural/grassroots/popular or Indigenous positions on colonial resistance are noticeably absent in this project, which focuses on elite intellectual, albeit political and sociologically oriented, artistic movements. This is especially surprising in light of the pioneering Indigenous collaborative practice employed by the Museo de Artes Populares, Mexico City (Nuestro Maiz 1981) or the subversive underground market networks of the Museo del Chopo, Mexico City, also in the 1980s (see Isaac et al. 2019).

Alongside new designations of 'ethnographic' collections as 'art', museums have also increasingly looked to contemporary or conceptual artistic interventions and juxtapositions to reinterpret objects that create dialogue and disturb the neutral narrative. The Weltculturen Museum in Frankfurt under the directorship of Clémentine Deliss, for example, created an object laboratory in which eight artists were invited periodically to make new works in response to pieces from the collection. This project, entitled Object Atlas: Fieldwork in the Museum, has been theorized as viewing the museum's collection as infinitely malleable and subject to multiple interpretations (Geismar 2015: 201). While the practice of including contemporary art in ethnographic museums hopes to disturb the traditional empiricist narratives often attributed to historic ethnographic collections, Geismar takes issue with the extent to which it constitutes a totalizing epistemology of its own, suggesting that the vantage point of the artist might not be as 'outside' of the museum as is theorized (Geismar 2015: 201). Geismar prefers Tony Bennett's semiotic materiality theory (2008) -- built on Latour's descriptions of assemblage (2005) -- to render different kinds of knowledge equivalent and thus dissolve the categorizations related to the supposed art/artefact divide. This position finds parallels in theories of archaeological collections, in which the term 'object biographies' has been replaced with 'object itineraries', so that the contexts represented and encapsulated by collections can be understood as spatial and temporal, converging in '.... sites and routes singular, multiple, virtual, and real' (Joyce and Gillespie 2015: 3). 
Multisensory art (Meyer 2009; Morgan 2012) in exhibitions can also be understood as part of the ongoing move to decolonize the underpinnings of the exhibition, which disciplines the body and privileges the eye by requiring visitors to stand in front of vitrines, looking at objects and reading texts. Furthermore, new perspectives on personhood and sensoriality usefully reject the essentialist divisions between people and things, and consider different experiential embodied ontologies (Strathern 1988; Gell 1998; Tilley 2004; Latour 2005; Alberti et al. 2011; Houston 2014; Alberti 2016). Multisensorial art - in the pre-Kantian sense of 'aesthetic' - or the deeper/plural semantic values associated with material culture that go beyond questions of beauty or function are of particular relevance to many Indigenous collections. The Museo del Barro in Paraguay, for example, exhibits popular, Indigenous, and 'modern' Paraguayan art on equal footing, considering all of these to be forms of 'contemporary art' (Power and Escobar 2012: 28). This choice aims to challenge the ethnocentric assumption that there are superior and inferior cultures that are worthy - or not - of producing significant expressions of the soul (Power and Escobar 2012: 28-9). Escobar speaks of the political relevance of Paraguayan popular art that is developed on the so-called periphery, contrasting it favourably with global contemporary art, which has arguably become de-radicalized by its association with the neoliberal market (Power and Escobar 2012: 35). The popular art he references demonstrates that the relationship between form and content is not binary but undecided and liminal; neither is it autonomous but contingent and dependent on specific contexts (Power and Escobar 2012: 37). Furthermore, Escobar contends, for example, that Indigenous ceremonial dress, deemed beautiful within its own cultural context, uses its aesthetic as a synecdoche for the plural meanings associated with it, many of which are outside the realm of the art itself (see also Damisch 1972 and Van Alphen 2005) and that, in trying to expose the unknowable and variable, these images work as a balm for the melancholy associated with their own failure to represent their deepest subject (Power and Escobar 2012: 15).

\section{Gaps and fragments}

Although anthropology and archaeology museums traditionally use their display collections to construct linear historical narratives, the collections of these institutions, which are displaced and outside their original system of meanings, have also been theorized as fragments (Shelton 2000: 13) - or a real image of false reality (Estévez González 2004) - which do not provide the totalized image of history or culture that museums aspire to (Shelton 2000: 13). While museum collections are made up of these fragments, Walter Benjamin, in On the Concept of History (1942 [2009]), describes the Angel of History in Paul Klee's Angelus Novus in this way:

His face is turned towards the past. Where we see the appearance of a chain of events, he sees one single catastrophe, which unceasingly piles rubble on top of rubble and hurls it before his feet. He would like to pause for a moment... to piece together what has been smashed. But... the storm drives him irresistibly into the future, to which his back is turned, while the rubble-heap before him grows sky-high. That which we call progress, is this storm (Benjamin 1942 [2009]: ix).

This text refers specifically to historical totalization and materialism, but Benjamin's analogy of the rubble-heap also evokes museum collections, which are made up of commodities that have been removed from circulation in the market (Henríquez and de Santa Ana 2019). The museum 'debris' continues to grow as curators are faced with a 'glut of choice' (Macdonald and Morgan 2018: 31) regarding potential new acquisitions. That said, the alienation engendered by the old project of museum ethnography can be countered through exhibitions that accentuate their gaps and disjunctures, rather than their coherences and connections. Structures such as these might galvanize understanding of the evolutions and creative adaptations that are characteristic of non-dominant societies in the context of epistemicide and disenfranchisement.

Archaeology, much like museum collections and exhibitions, is also based on fragmentary material, and studies are biased on the basis of what remains, as well as who is interpreting those remains. Exhibitions of archaeological material have, as shown above, largely promoted uncritical perspectives of Latin American pre-Columbian cultures by displaying supposedly neutral archaeological material and interpretations. Meanwhile, the 
rise of right-wing populism, neoliberal culture wars and ongoing systemic racism have meant that certain governments mobilize support through a misrepresentation of contemporary societies, fostering an imaginary of an unproblematic pre-global era in which culture was uncontested and inhabited specific locations. Anthropological and archaeological exhibitionary projects could eschew neutral narratives by, for example, overtly politicizing the material they display. By accentuating the gaps and fragmentation in ancestral knowledge that are a result of power imbalances between what is defined as the global south and north, exhibitions can be deployed against the social injustices that are the legacies of early anthropological collecting and that continue to be perpetuated by museums. Radical cosmopolitics or the World Anthropologies movement, as part of the decolonizing debate in academia (Tuhiwai Smith 1999; de Sousa Santos 2014; Henriques et al. 2017; Mignolo and Walsh 2018; de Sousa Santos 2018), which follows on from earlier critiques of anthropology (Asad 1973; Hymes 1974; Harrison 1991) emphasize the asymmetrical power relations that problematize geopolitical 'knowledge'. While anthropological knowledge is written as being transcendental, the 'West', through colonialism and related systems such as nations and academia, has disseminated a self-referential knowledge (Ribeiro and Escobar 2006; Ribeiro 2014; de Sousa Santos 2014). The World Anthropologies agenda has been to favour diversity through intercultural rather than multi-cultural dialogue, a project which involves increasing the visibility of Indigenous perspectives. de Sousa Santos argues that the 'epistemologies of the south' are inseparably intertwined with the political struggles from which they originate and the epistemicide they are confronted with. As such, this definition of epistemologies is not the same as that applied to the epistemologies of the north, in that they are not studies of a particular knowledge system or field. Rather, they represent that which is not considered knowledge by the self-legitimating system that it is oppressed by, and in this way they constitute practices of resistance (de Sousa Santos 2018, 2-3). The pluriversality they support is based on the recognition of the copresence of other knowledges and the need to study the divergences and complementarities among them (de Sousa Santos 2018: 8). Epistemologies of the south are also discussed and deployed in terms of local languages. The word chachawarmi, for example, denotes culturally specific Quechua notions of gender and has been taken up in women's liberation struggles in some countries in Latin America (de Sousa Santos 2018: 10). de Sousa Santos describes this word and its mobilization as a contribution to existing feminist rhetoric in the sense that it does not (as opposed to the Foucauldian tradition) rely on knowledge being separated from the experiences of the subject of that knowledge (de Sousa Santos 2018: 4).

What follows is a discussion of the exhibition Arts of Resistance: Politics and the Past in Latin America, (MOA, UBC 2018). The exhibition was funded by the MOA, the Mellon Foundation and the Michael O'Brien Family Foundation and, as such, was not affiliated to or sponsored by a nation state or highly political bodies such as Latin American embassies and heritage institutions. It displayed visual and material culture made by individuals or collectives that use historical events and images in radical solidarity of their own or other marginalized communities from across Central and South America, in order to illustrate that these arts can be considered a form of action and resistance against hegemonic cultural representation and management. Some of these works document histories that have been or are in the process of being repressed through state-sponsored violence. Others show how artistic communities from dependent market economies, whose work has been promoted for its picturesque qualities to conform with the interests associated with a folkloric art boom that has served to historicize many Indigenous Peoples (Baud and Ypeij 2009; Berger 2016), can twist or subvert typical narratives in order to communicate contemporary social or political evolutions or realities. Certain other works adopt global art trends while imbuing them with local and ancestral meanings, materials, and styles. Finally, the exhibition included artistic traditions that do not represent or visually communicate social or political narratives but instead are a testament to the role of ancestral creative culture as an economic and psychological tool in the face of marginalization and oppression. The exhibition also provides political context for the ongoing transmission of creative and material ancestral knowledge in spite of the challenges posed by the ongoing layering of colonizing projects. Finally, and most saliently in the case of museum archaeology, this exhibition shows Indigenous, minority and diasporic reinventions, manipulations, fragmentation or anachronization of pre-Columbian or historical 
images, art forms and ideas. These practices constitute an abstraction and re-appropriation of the study of the past and 'archaeological heritage'. The exhibition included works from various countries in Central and South America, not in order to create a false or homogenized representation of Latin America, but rather to create a visual and material dialogue between these independent political contexts. The project bears witness to the struggle by the communities involved for recognition of their knowledge both locally and internationally in the context of racism and human rights violations against them. This paper intends to show that the past and pre-Hispanic civilizations of Central and South America can be a critical forum activated by contemporary makers, artists and activists, which can mobilize complex narratives to counter those promoted by dominant sectors of society, whether they be scientific (academic) or governmental. The pluriverse/multiverse argued for in cosmopolitical theories implies that, while it continues to be necessary to disturb the self-referential knowledge and historical totalization that museums have promoted, there is not one museological paradigm shift that will form a counter-narrative but, rather, contradictions and affinities embodied in these fragments constitute active pockets of resistance (Berger 2001).

\section{Arts of Resistance in the Exhibition}

\section{Ollin}

The exhibition was divided into five object groups or installations, Alternative Histories, Soft Power, In Defence of Maize, Sympathy for the Devil and Living Design, separated from each other by white translucent gauze hung from ceiling to floor to form curved spaces. This design (viewed vertically) was based on the pre-Columbian Mexica day sign, ollin. Roughly translatable as 'movement', this day in the Mexica calendar was associated with shifting celestial bodies, transmutation, disorder and seismic change. The curved partitions force the visitor to respond kinaesthetically (see Tilley 2004) to an Indigenous Mesoamerican concept that evokes temporal cyclicality and periodic cosmology, as well as historical and ritual extinctions and renewals of the universe, thereby critiquing 'Western' temporal and historical linearity. The section entitled Sympathy for the Devil included dress elements from the Huejotzingo festival in Puebla, Mexico, a carnival that is held during the five days before Shrove Tuesday. Huejotzingo is near the pre-Columbian ceremonial complex at Cholula, where Spanish missionaries built a cathedral at the apex of the largest temple structure. The carnival celebrates various historical and legendary local events, the largest of which is the Battle of Puebla (5 May 1862), in which the armies of Napoleon III were repelled by a small contingent of Mexican forces. The re-enactment of this battle involves extensive use of gunpowder in hand-carved muskets and includes various groups who constitute the Mexican forces, such as Indigenous armies from Zacapoaxtla and Serrano (both other towns in Puebla), Apaches and Aztecs (who fight in pre-Columbian dress and weaponry), Negritos (Mexicans of African descendent), the emissaries of the pre-Hispanic creator god Huitzilopochtli, and devils (Guzman Carcaño 1993). Disparate myths, chronologies and histories coalesce to mark a temporary breach in linear time, where everyday experience of time and place collapse in a Timequake. ${ }^{3}$ By re-activating aspects, ideas and images from the region's past and fracturing and reconstructing time and space while celebrating a local victory, in defiance of national celebrations, this practice may also ease the burden of the debris of history (Benjamin 1942 [2009]).

A Maya tunic, or xicul, exhibited in the textile section of the exhibition, entitled Soft Power, was commissioned from the late Chankin Tercero, a Lacandon artist from Naha on the Mexico/Guatemala border. Tercero lived in Palenque, where he sold, and his family continue to sell, tourist arts based on ancestral practices and knowledge at the entrance to one of Mexico's most internationally recognized, frequented and researched archaeological sites. His family has actively engaged in Lacandon ethnographies since the Lacandon tropical forest began to be heavily logged; his grandfather, old Chankin, had been the main respondent to both Frans and Gertrude Blom, as well as Robert Bruce (Perera and Bruce 1985). These tunics are made with ficus tree bark, which is processed by repeated soaking and flattening 


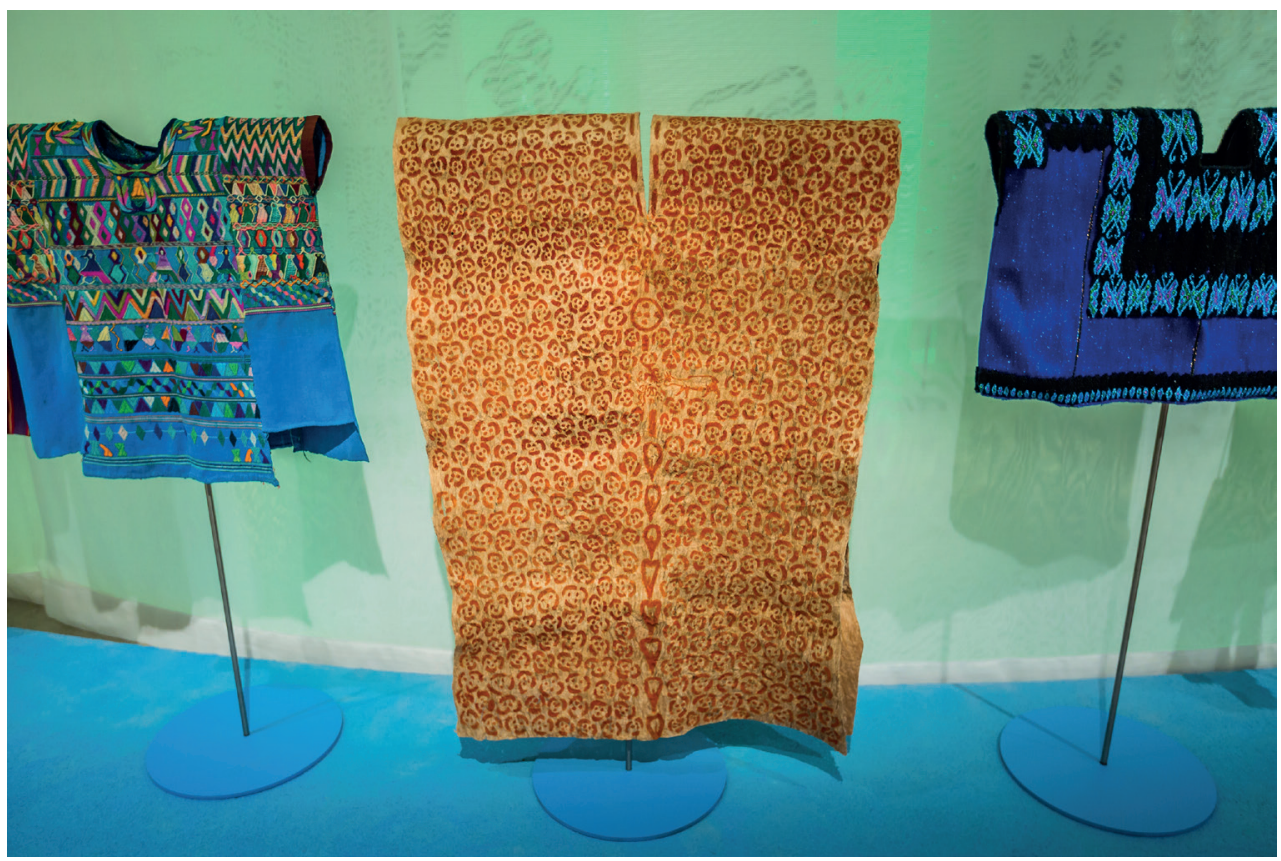

Figure 1. Xicul (bark-cloth tunic). (MOA no. 3289/21) Artist: Chankin Tercero. Photo by Sarah Race

of the material and, once the bark has been adequately stretched and dried, it is painted with achiote - annatto seed designs. Early or traditional achiote designs, such as those on the tunics in textile collections such as at the Museo Nacional de Antropología in Mexico City or the Centro de Textiles del Mundo Maya, San Cristobal de las Casas, were simple and circular, but Chankin Tercero innovated on the designs, entering his more elaborate works into national Mexican folkloric art competitions organized by SEDESOL ${ }^{4}$ and FONART. ${ }^{5}$ Tercero indicated that the drops of water painted vertically down the front of the tunic (figure 1) represent the sacred substance k'uh also depicted on the Maya Classic period relief sculpture decorating Pakal's sarcophagus at Palenque, and that the figures in the centre of the tunic were inspired by the rock paintings at the sacred Lacandon Metsabak lake (Sánchez Balderas 2005). These diminutive figures were interpreted by Tercero as aluxes, small people who are rarely visible and are said by contemporary Mayas and Mayan speakers to have been made by preColumbian Maya ritual specialists to protect their territory, explaining their association with places of historical significance, such as archaeological sites. Although aluxes appear regularly in contemporary Maya historical and existential philosophies, their significance is generally not considered in the interpretation of pre-Columbian Maya culture by many archaeologists, since there are no references to them in ethnohistorical literature, and they are understood to be a modern Maya narrative feature (Xiu Cachón 1993; Villanueva 2014). The scientific interpretation of sites such as Palenque and the revenue they generate from tourism are in most cases the privilege of the international and Mexican elite - academic, governmental and commercial - that sideline Maya interpretations and practices. Tercero's family may depend precariously on the market structures that are currently in place at Palenque and in Mexico, and their art is predominantly deemed valuable in the folkloric and touristic art context, but the bark cloths they make contain their own interpretations of ancestral Maya culture, material and otherwise. This can be considered a form - however inexplicit or visually apolitical - of cultural re-appropriation by a contemporary Maya artistic community of Maya history and pre-Columbian Maya art by a contemporary Maya artistic group. 


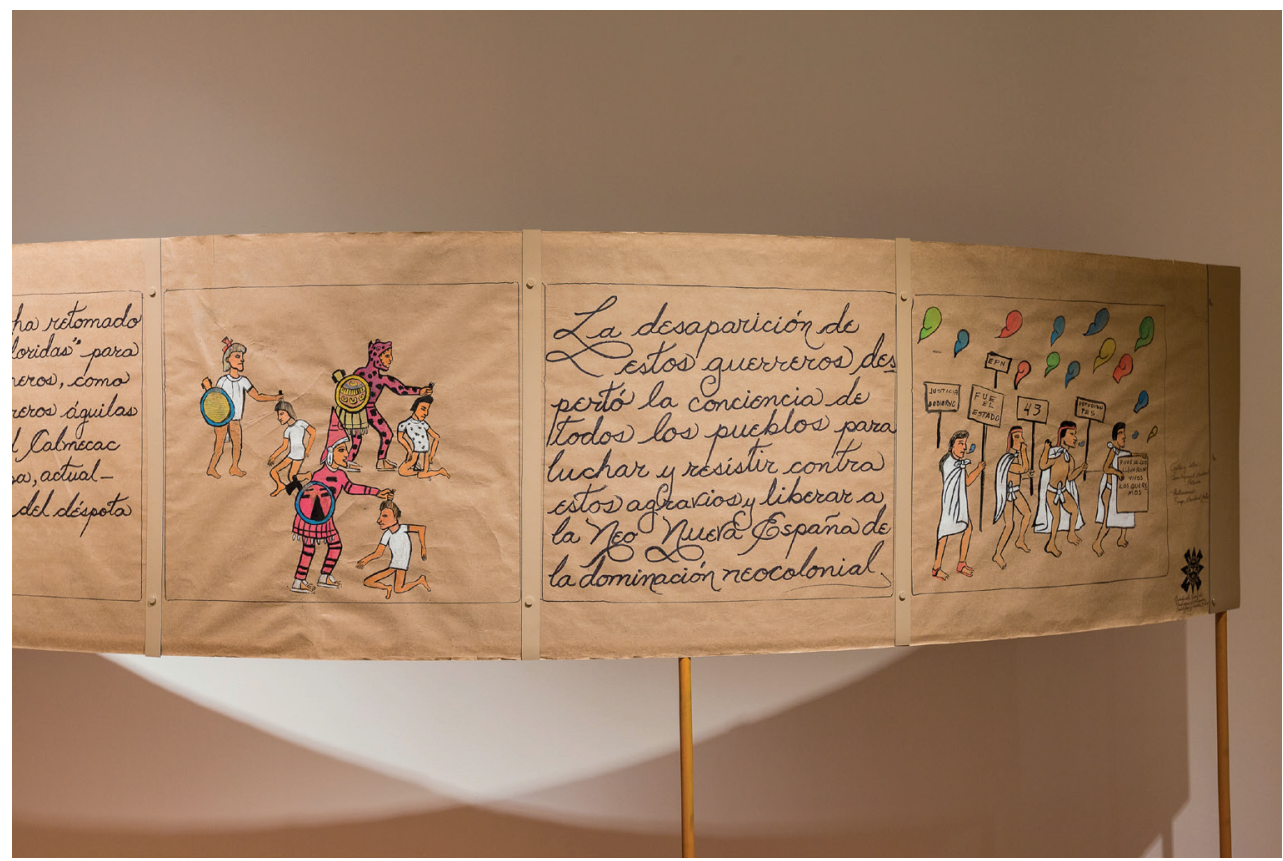

Figure 2. Excerpt from the 'Ayotzinapa Codex'. (MOA no. 3289/20) Artists: Juan Manuel Sandoval and Diego Sandoval Ávila. Photo by Sarah Race

Another example of local interpretation and re-use of historic image and material is the Ayotzinapa Codex (figure 2), which documents the events of 26 September 2014, when 43 male students from the Escuela Normal Rural Raúl Isidro Burgos in Ayotzinapa - a school for Nahuatl-speaking teachers in Mexico - were forcibly disappeared. Their disappearance has widely been attributed to a local drug cartel that has been shown to be in collusion with state authorities (Osorio Sunnucks et al. 2018). ${ }^{6}$ The authors of the work, Juan Manuel Sandoval and Diego Sandoval, view the Mexican state as the ideological descendant of its sixteenth century colonial administration and attack the neoliberal policies of what is described in the codex as 'New Spain'. The text likens the 43 disappeared students to prisoners captured in pre-conquest Mexica warfare, while the text and iconography of the codex associates Mexico's contemporary Indigenous peoples with the subjects of New Spain in post-conquest Mesoamerica. This reference to Mexica warfare includes illustrations of capture and sacrifice, critiquing the mechanisms of the pre-conquest Aztec empire, as well as those of Spanish colonial oppression. This conscious conflation of cultures and histories emphasizes the problems inherent in dominant systems of governance - in that they are neither temporally nor culturally specific. In the early decades of Spanish colonial administration, codices were used by Indigenous Peoples in what is now Central Mexico to petition the government to recognize Indigenous territorial ownership and uses, and these manuscripts frequently employed both Mesoamerican and European representational styles. The Ayotzinapa Codex is a descendant of these works, consciously playing on cultural hybridity to create a temporally complex but coherent statement on contemporary racial politics in Mexico. Juan Manuel Sandoval and Diego Sandoval donated the work to the families of the disappeared students, so that the sale of the work to the MOA,UBC would benefit their ongoing lobby to the Mexican government. ${ }^{7}$ Notably, the exhibition's opening reception was not attended by any representatives from Latin American consulates or embassies in Canada and the Mexican consulate in Vancouver expressed their disappointment that the Codex Ayotzinapa was displayed on the basis that they felt the work undermined governmental efforts to investigate the student disappearances. 


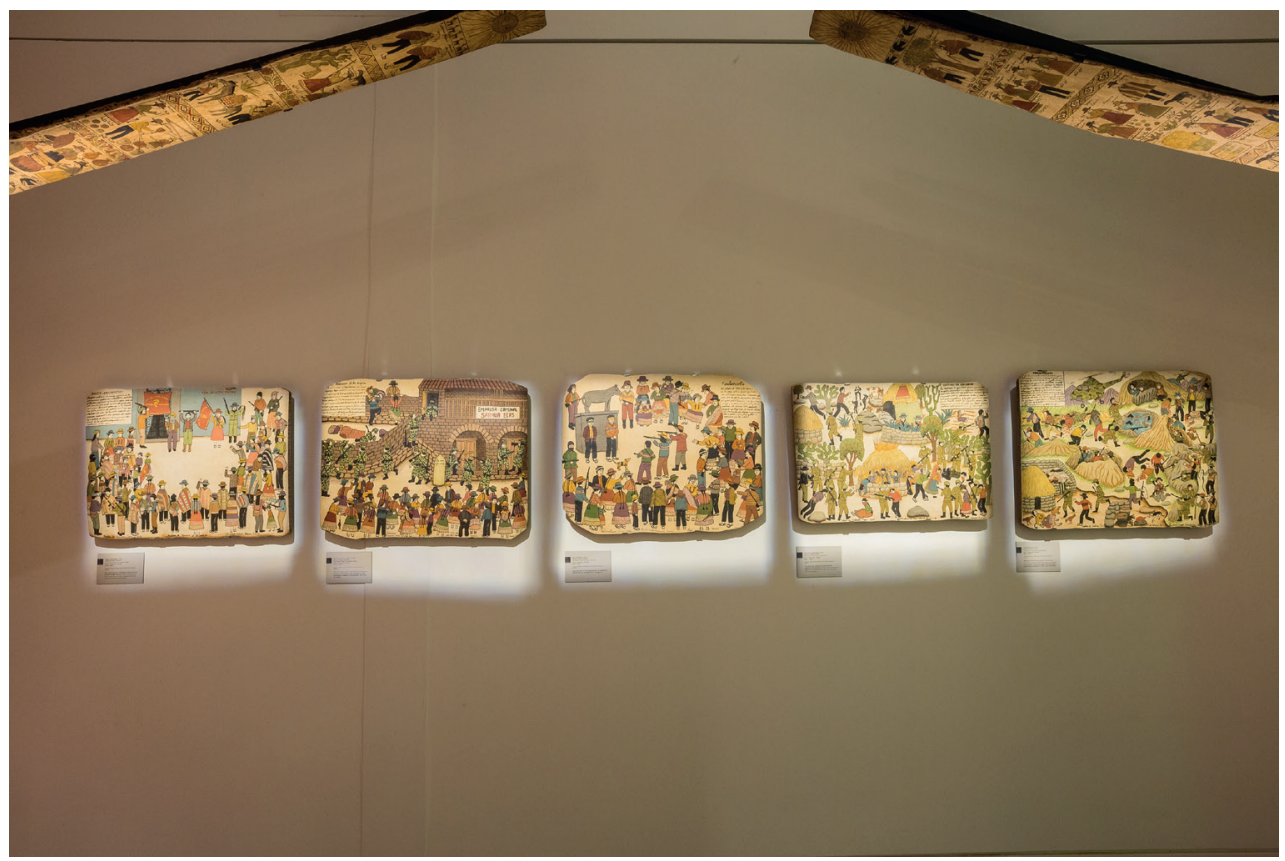

Figure 3. 'Piraq Causa?' (MOA nos. 3289/62, 3289/63, 3289/64, 3289/65, 3289/66) and two Sarhuino painted roof beams (MOA nos. 3289/60 and 3289/61) Artist: Venuca Evanan Vivanco (reproduced after Primitivo Evanan Poma). Photo by Sarah Race

\section{Diverse Documents}

The Ayotzinapa Codex described above was exhibited alongside other narratives in the section Alternative Histories, which was dedicated to marginalized community memory documentation that uses or incorporates ancestral knowledge or style. Another group of works in this section were seven paintings created by Venuca Evanan Vivanco, the daughter of Primitivo Evanan Poma. Evanan Vivanco and Evanan Poma currently reside in Lima but are originally from Sarhua, Ayacucho, Peru, an area that was severely affected by the Shining Path and paramilitary clashes of the 1980s (figure 3). The series of five horizontal paintings, entitled Piraq Causa (Who is to blame? in Quechua) are replicas made by Venuca Evanan Vivanco, who leads a diasporic Sarhuino cultural revitalization project in Lima, of those originally made by her father Primitivo Evanan Poma in the wake of the Shining Path (Sendero Luminoso) and Peruvian military conflict. The diagonally hung beams that recall slanted roofs are also reproductions made by Evanan Vivanco, in this case of works made by her grandparents in Sarhua, before her family moved to Lima. They are part of a community tradition of painting for newlyweds, in which family genealogies and religious and social rituals are collaboratively inscribed onto the wooden beams of their houses, as a means of transmitting cultural knowledge to younger generations. The newer painting format created by the ADAPS (Association of Popular Artists from Sarhua), of which Evanan Poma was a member, is executed on rectangular boards and was originally used to document the 'times of danger' in the 1980s. The Piraq Causa series denounces the human-rights abuses committed both by guerrilla insurrectionists and the state military. One of the paintings in the series, entitled Onqoy (sickness in Quechua, figure 4) has appeared in three different versions, made in 1986, 1992 and 1996. These repetitions show distinctive variations, including the deletion of certain details associated with Sarhuino relations with the Shining Path movement, and it has been argued that this kind of erasure of the past reveals the community desire to move forward, without dismissing the impact of 
the traumatic past associated with the Maoist insurgency (González 2010). It has also been suggested that in their attempt to reverse the trauma of war, these artists have repeated a painful and compromising event as a means of voluntarily repressing it, an 'un-remembering' or 'remembering to forget' that involves the repetition of the act of erasure, in turn giving visibility to the experience with the aim of ultimately forgetting and making room for new perspectives. ${ }^{8}$ This analysis challenges recent accusations made against the 1992 version of Onqoy, which was confiscated in October 1997 by Peru's Counter-Terrorism Directorate (DIRCOTE ${ }^{9}$ ), who are investigating paintings on the basis that they may be an apologia for terrorism. Following the 'times of danger', there has been substantial out-migration from the Ayacucho region, and Evanan Vivanco has expressed fears that this will lead to a loss of community identity. ${ }^{10}$ Her reproductions of these paintings from the recent traumatic past are sold and exhibited in her community workshop alongside other elements of ancestral Sarhuino practice and contemporary innovations on this painting style. While these new works and reproductions could be judged as necessary outputs that maximize the fame and respect the ADAPS has garnered both nationally and internationally, they can also be understood as a political reappropriation of the documentation of local history by a community who were made victims of state-sanctioned terrorism in the context of geopolitical tension.

Another group of works on display in this section were made by the Panzaleos (or Kichwa) peoples of the Tigua valley in Cotopaxi, Ecuador. These illustrate various local contexts and practices, including ritual and ceremonial life, sacred landscape and agriculture, traditional and newer local infrastructure, and Indigenous uprisings against military figures. These heterogeneous images, albeit with similar naively rendered landscape contexts, are painted onto sheepskin and stretched over a rectangular frame made from laurel-tree wood. Tigua painting, which was developed in the mid-1970s during the folkloric art boom and saw increased productivity after the economic crisis of 1982, is based on previously existing material knowledge employed in the making and painting of ceremonial masks and drums, and was galvanized through relationships between communities in the region and collectors from the capital city. As such, while Tigua paintings can be considered a form of ancestral cultural heritage and local expression, and while the Panzaleos consider it a duty to defend

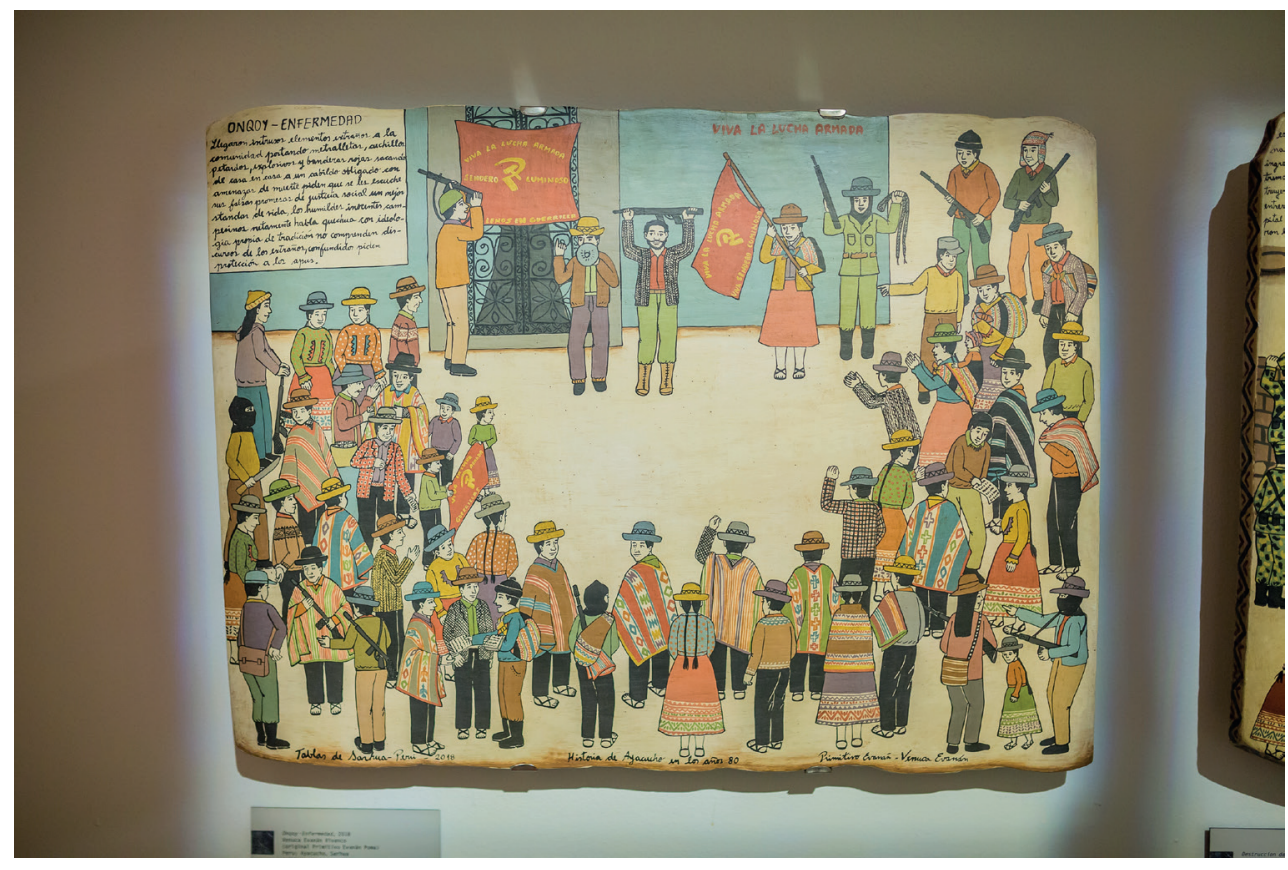

Figure 4. 'Onqoy'. (MOA no. 3289/66) Artists: Venuca Evanan Vivanco (reproduced after Primitivo Evanan Poma). Photo by Sarah Race 


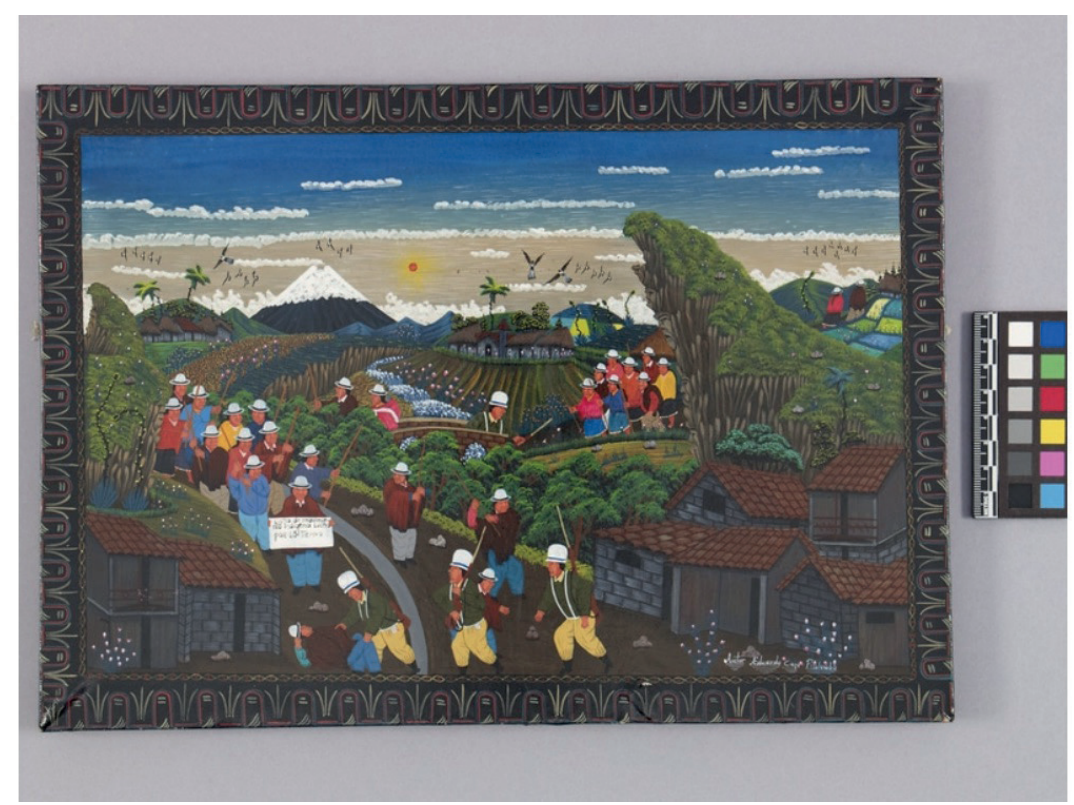

Figure 5. Tigua Painting. (MOA no. 2903/54) Artist: Eduardo Cayo Pilalumbo. Blanca and Ricardo Muratorio Collection. Photo by Kyla Bailey

and sustain their identity, local practices and territories, the paintings are explicitly made for external audiences through the touristic and collecting market (Muratorio 2000; Valiñas López 2008). The painting by Eduardo Cayo Pilalumbo (pictured in figure 5) shows an uprising in which the local inhabitants confront military figures holding a banner that reads, 'Lucha de movimiento indigena. Lucha por La Tierra'.11 The foreground of the scene shows various brick and tiled roof buildings, which demonstrate the modernization of traditional housing and thereby communicate the artist's view of local development to a globalized world. This painting movement has been a vehicle for community economic development but, in this way, it has also been a medium capable of redefining and placing value on a cultural identity that had been eroded by centuries of colonial policy and various forms of racial abuse (Valiñas López 2008). Furthermore, the themes that artists such as Cayo Pilalumbo engage in reveal tensions between perceptions of the Tigua valley as a dependent market economy responding to the demand for idealized depictions of local or Indigenous life in South America, and a reality in which communities are actively involved in cultural and identity management on a local and global scale. Furthermore, in showing ancestral culture and non-dominant religion alongside activism and economic and infrastructural development, the so-called Tigua paintings resist the historicization of Indigenous Peoples and can broker new relationships with the dominant non-local institutions who manage the representation of their culture.

\section{Street Painting}

Two installations by street mural artists in Latin America were created in the gallery to illustrate the appropriation and disarticulation of global art trends by the so-called periphery, in which new symbolic languages subvert globally dominant art forms. While political murals are common in 'Hispanic' and Latin American art, for example the Mexican muralists of the post-revolutionary period and the Chicano street art movement, political street wall painting has flourished across Latin America (see De Parres Gómez 2017; Dabène 2019). The installation, In Defence of Maize, was made by the Oaxacan collective Lapiztola using hanging paper stencils (figure 6) designed in 2006 during the APPO (Asociación Popular del Pueblo de Oaxaca) uprising, to reproduce the image in silkscreen on the gallery wall 
(figure 7). The 2006 APPO conflict was sparked when the police opened fire on teachers participating in a peaceful protest against funding cuts for rural schools, and authorities were eventually forcefully ejected from the city centre, causing a siege that lasted several months, during which time the colonial walls of the city centre were covered in subversive words and images denouncing the local governmental human-rights abuses and contesting tourist-oriented neoliberal policies, as well as the commercial appropriation of Indigenous culture for non-Indigenous profit. The image shows a woman in Indigenous dress pointing a rifle at the fictionalized engineers of transgenic maize, wearing de-personalizing hazmat suits with a background of lurid green light. Maize agriculture is at the root of Mesoamerica's earliest civilizations and its replacement by the less nutritious transgenic varietal, imported and distributed by international corporations in association with the Mexican government, has substantially affected the Indigenous and locally grown maize market. The original message links resistance against transgenic maize with Indigenous empowerment while its gallery iteration, in which the collective has inserted pre-Hispanic depictions of the maize goddess, Centeotl, into the backdrop of the silkscreen image, associates contemporary Indigenous struggle with historical Mesoamerican religion. Mesoamerican history is thus weaponized against neo-colonial processes, emphasizing that international/national marketization of maize culture implies not only an economic and nutritional loss, but also the loss of religious identity and ancestral culture. The stencils, which owe their aesthetic in part to global graffiti and street art styles, have been cut by hand, rather than with the aid of digital, laser equipment and while this choice is based on economic necessity, Lapiztola's work references the handmade popular and Indigenous arts of the region.

Another installation, placed at the exit to the exhibition, entitled Living Design, was dedicated to an eight metre by four metre mural painted onsite by artist collective members Reshijabe, also known as Olinda Silvano, and Runin Kaysi, also known as Silvia Ricopa, who are members of the Shipibo-Konibo diaspora in Lima, Peru, who moved there from the Amazonian Ucayali riverine region in the 1990s, following a decade of political violence in the region. The installation showcased kené design (figure 8 ) which, based on the patterning of the universal and primordial Shipibo-Konibo anaconda, is strongly associated with healing and powerful plants. In order to materialize kené, a design which is traditionally applied to ceramic,

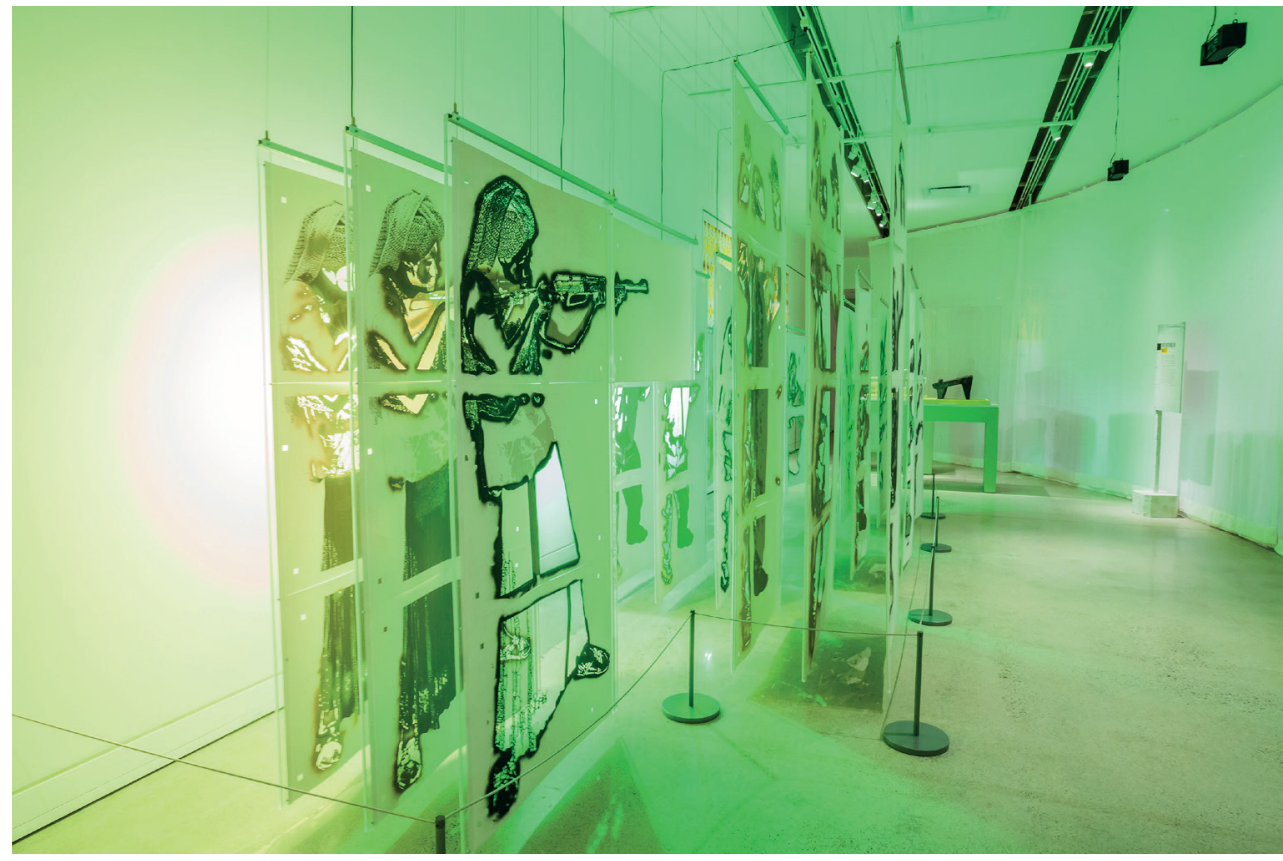

Figure 6. 'La Defensa del Maíz'. Artists: Lapiztola collective. Photo by Sarah Race 


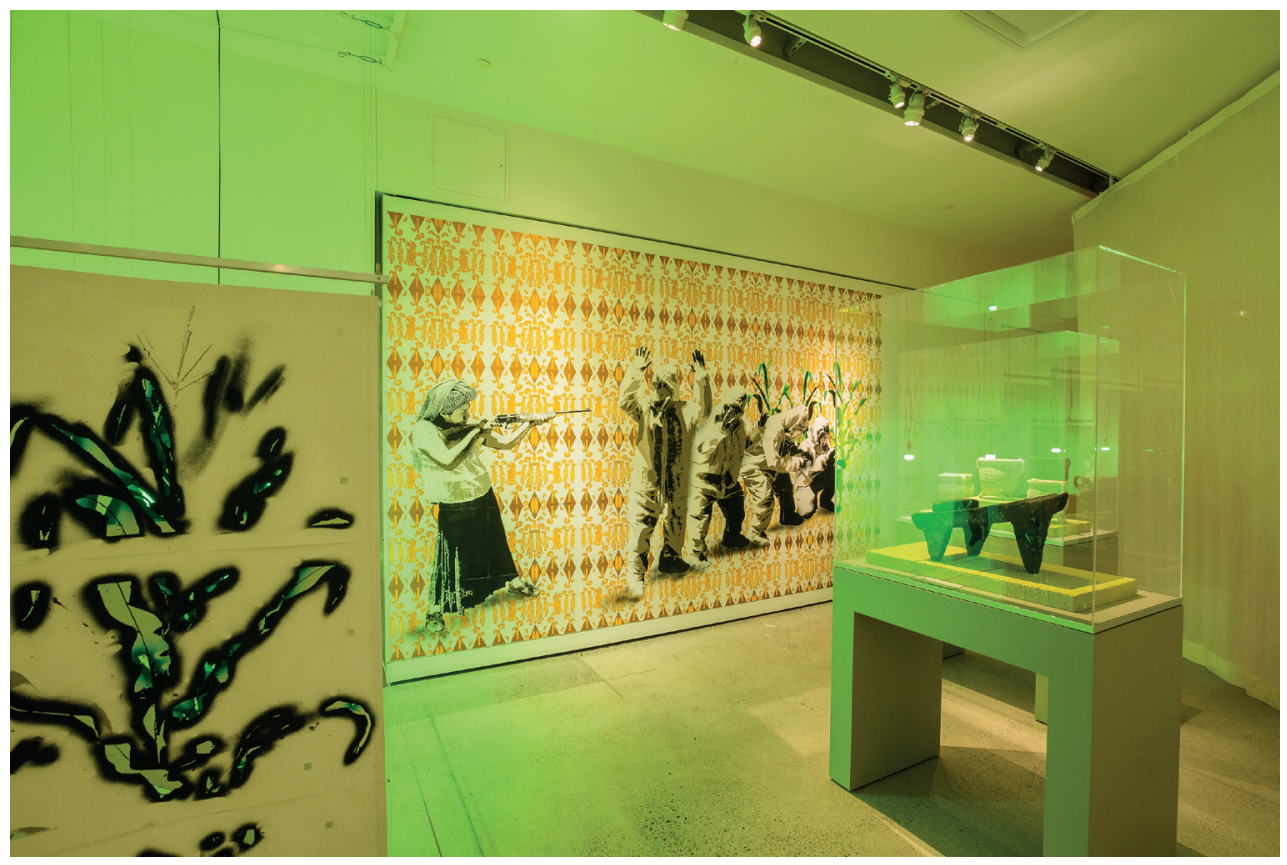

Figure 7. 'La Defensa del Maíz'. Artists: Lapiztola collective. Photo by Sarah Race

textile and skin must first be visualized, usually in dream states. While it is predominantly men who practise healing with powerful plants, traditionally only women are able to evoke and thus depict kené. Silvano and Ricopa described kené as follows: 'Runi is the mother of the earth, water, and fish. If Runi were to die, the river would become dry and earth would lose its strength'. The design on the right is a symbolic representation of this all-powerful force, while that on the left is a symbolic map of the Ucayali region, in which the thick black lines, which represent the forest, and the blue lines, which represent the riverine system, are filled with energy. These symbolic pathways have also been associated with the movement of the Shipibo-Konibo diaspora, spatially and culturally over time (Belaunde 2009). Silvano and Ricopa sang while they painted the mural and later described this action as a transfer of their living ancestral culture into the design..$^{12} \mathrm{~A}$ recording of this singing was played as part of the installation, creating a multi-sensorial experience and thereby communicating the traditional Shipibo-Konibo reception of kené. The diasporic Shipibo-Konibo community is known for its strong relationship with the tourist art market; in the context of economic hardship and social discrimination, kené has provided women such as the members of Silvano and Ricopa's collective with a means of generating income. Furthermore, the dissemination of this artistic tradition has, arguably, had a positive impact on Amazonian Indigenous and non-Indigenous relations in Peru. The first kené mural was made in San Isidro, Lima in 2016, following the annihilation of the Shipibo-Konibo neighbourhood of Cantagallo by a fire which, although not deadly, resulted in the loss of the community's homes and belongings. Silvano and Ricopa acknowledged that the practice of invoking and making kené, both privately and for wider audiences, has helped them to recover from the tragedy of the fire. Their murals reclaim public space for an Indigenous diasporic community who have suffered from discrimination and social abandonment, while prompting us to consider the role of creative cultures in the context of socio-economic disenfranchisement. While the installation does not reference political context directly, Indigenous agency and politics are deeply embedded in the existence of this diasporic art form and, as an Indigenous-directed project, the work of Silvano and Ricopa's collective is an invaluable contribution and response to the global street art movement. Kené is an example of local art that has clear aesthetic, sensory components encompassed in a 
much broader social role (Power and Escobar 2012), one that involves community economic development as well as psychological, social and physiological healing.

Arts of Resistance: Politics and the Past in Latin America focused on creative communities whose work upsets traditional representations of cultural history, redeploying the past against political and cultural hegemony. In the museum context, these arts subvert the totalizing and processual historical narratives that these institutions are known for. The buying and inclusion of work made by marginalized artistic communities constitute a form of curatorship for social justice, mobilizing contemporary art in more ways than its potential to manifest multiple interpretations suggests. The rise of right-wing populism, through which politicians sustain and fan cultural essentialism and racism, alongside increased critique of museum inertia and lack of accountability in the public sphere, imply that cultural dialogue is increasingly important. Unfortunately, anthropology museums with collections built with and through colonialism, which continue to perpetuate systemic racism, do not look likely to provide spaces of ideological freedom and criticality. This paper argues for harder forms of overt politicization in museums, to demonstrate the lack of neutrality underlying curatorial projects and so engender debate and action. In the context of exhibiting material from the

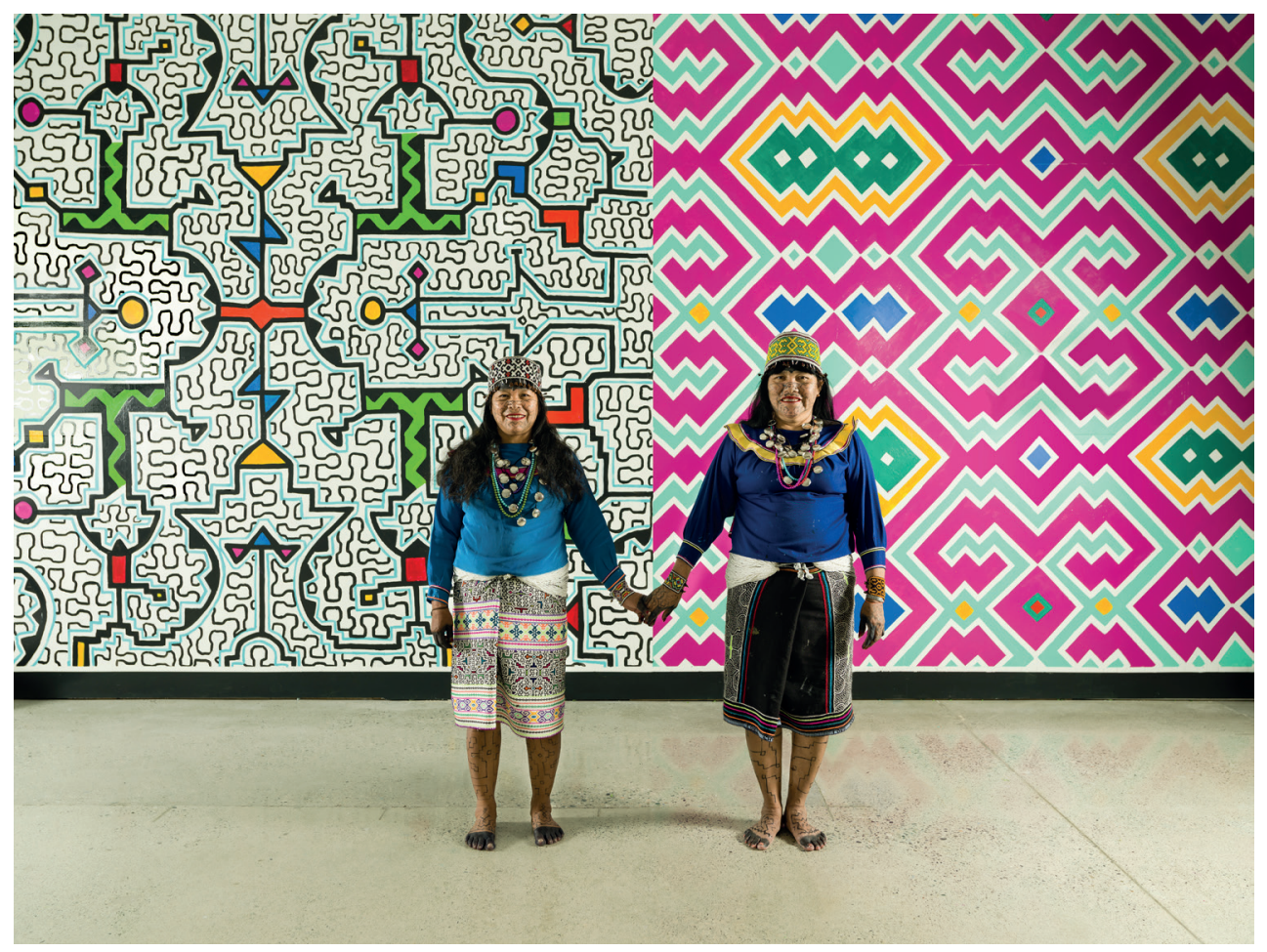

Figure 8. Kené mural. Artists: Olinda Silvano and Silvia Ricopa. Photo by Alina llyasova

global south, a cosmopolitical framework can be useful in showing how cultural resistance is manifested diversely, while containing affinities and resonances inter-regionally. As in the widespread use of Indigenous and local words, the dissemination of Indigenous and local creative practices can rupture paradigmatic knowledge and counter racism. Although many of the works included in the exhibition communicated political positions, there was no explicit acknowledgement of the role of curatorial choice in the creation of the field collection and didactic content. Future projects will go further in disturbing the authorial voice of the museum by making their curatorial standpoint visible. 


\section{Notes}

1 Paisajes de la Violencia en Colombia, 'Construcción metodológica', 2018. http:// www.centrodememoriahistorica.gov.co/micrositios/recorridos-por-paisajes-dela-violencia/wiwa.html, accessed 3 March 2021.

2 Nika Chilewich, 'When Latin American Art Took a “Decolonial Turn”, , Hyperallergenic 5 September 2018. https://hyperallergic.com/458260/when-latin-american-arttook-a-decolonial-turn/ accessed 3 March 2021.

3 Anthony Shelton, Director of Museum of Anthropology, University of British Columbia, after Vonnegut 1997, personal communication, 5 December 2017.

4 Secretaría de Desarrollo Social.

5 Fondo Nacional para el Fomento de las Artesanías.

6 Alberto Arce, 'La 'verdad histórica' sobre los estudiantes desaparecidos en México sufre otro revés', New York Times 9 February 2016. https://www.nytimes.com/ es/2016/02/09/espanol/america-latina/la-verdad-historica-sobre-los-estudiantesdesaparecidos-en-mexico-sufre-otro-reves.html, accessed 3 March 2021.

7 Guillermo Rivera, 'Códice que denuncia la desaparición de los 43 de Ayotzinapa llega a museo de Canadá', Sinembargo 27 March 2018. https://www.sinembargo. mx/27-03-2018/3401578, accessed 3 March 2021.

8 Olga González, Associate Professor of Latin American Anthropology, Macalester College, personal communication, 15 November 2017.

9 Dirección Contra el Terrorismo.

10 Venuca Evanan Vivanco, Artist, Asociación de Artistas Populares de Sarhua (ADAPS), personal communication, 16 January 2018.

11 'Indigenous Activist Movement. Fight for our Lands'.

12 Olinda Silvano and Silvia Ricopa, Cantagallo Artist Collective, personal communication, 5 May 2018.

\section{References}

Acuña Suarez, J. and Miranda, M.M. (2018) 'Interdisciplinary Research on Material Culture and Heritage of the Camëntsá People', Objects from Indigenous and World Cultures: Conservation Newsletter 3.

Alberti, B. (2016) 'Archaeologies of Ontology', The Annual Review of Anthropology 45163 79.

Alberti B., Fowles S., Holbraad M., Marshall Y. and Witmore, C.L. (2011) "Worlds Otherwise': Archaeology, Anthropology and Ontological Difference', Current Anthropology 52 (6) 896-912.

Ames, M. (2003) 'How to Decorate a House: The Renegotiation of Cultural Representations at the University of British Columbia Museum of Anthropology', in Laura L. Peers and Alison K. Brown (eds) Museums and Source Communities: A Routledge Reader, 171-80, New York: Routledge. 
Asad, T. (1973) Anthropology and the Colonial Encounter, New York: Humanities Press.

Bakhtin, M. (1981) The Dialogic Imagination: Four Essays, Austin: University of Texas Press.

Baud, M. and Ypeij, A. (2009) Cultural Tourism in Latin America: The Politics of Space and Imagery, Leiden: Brill.

Beardsley, J. and Livingston, J. (1991) 'The Poetics and Politics of Hispanic Art: A New Perspective', in Ivan Karp and Steven Lavine (eds) Exhibiting Culture: The Poetics and Politics of Museum Display, 104-20, Washington DC: Smithsonian Institution Press.

Belaunde, L.E. (2009) Kené: arte, ciencia y tradición en diseño, Lima: Instituto Nacional de Cultura.

Benjamin, W. (1942 [2009]) On the Concept of History, Scotts Valley: CreateSpace Independent Publishing Platform.

Bennett, T. (2008) 'Anthropological Assemblages: Producing Culture as a Surface of Government', CRESC Working Paper Series 52.

Berger, J. (2001) The Shape of a Pocket, London: Bloomsbury.

Berger, M. (2016) From Ollamaliztli to Pelota Mixteca and Beyond: The Role of Globalization in the Historical Development of an Indigenous Mexican Ballgame. Unpublished Phd dissertation.

Binter, J.T.S. (2019) 'Beyond Experiencing the Experience of Empire: Challenging Chronotopes in the Museum', Third Text 33 (4-5) 575-93.

Bourdieu, P. (1984) Homo Academicus, Peter Collier (trans) Stanford, CA: Stanford University Press.

Buchli, V. and Lucas, G. (eds) (2001) Archaeologies of the Contemporary Past, London/ New York: Routledge.

Buntinx, G. (2006) 'Communities of Sense/Communities of Sentiment: Globalization and the Museum Void in an Extreme Periphery'. in Ivan Karp, Corinne A. Kratz, Tomás Ybarra-Frausto, and Lynn Szwaja (eds) Museum Frictions: Global Transformations/ Public Cultures, 219-46, Washington, DC: Smithsonian Institution Press.

Cameron, F. and Kenderdine, S. (eds) (2007) Theorizing Digital Cultural Heritage: A Critical Discourse, Boston, MA: MIT Press.

Clifford, J. and Marcus, G.E. (1986) Writing Culture: The Poetics and Politics of Ethnography: A School of American Research Advanced Seminar, California: University of California Press.

Cojtí Ren, I. (2015) 'Los logros y retos de la población Maya por recuperar su herencia histórica', in Maarten E.R.G.N. Jansen and Valentina Raffa (eds) Tiempo y Comunidad: herencias e interacciones socioculturales en Mesoamérica y occidente, 229-34, Leiden: Leiden University Press.

Collison, J.N. and Steedman, S. (eds) (2011) That Which Makes Us Haida - the Haida Language, Skidegate: Haida Gwaii Museum. 
Colwell-Chanthaphonh, C. and Ferguson, T.J. (2007) Collaboration in Archaeological Practice: Engaging Descendant Communities, Plymouth, UK: Altamira Press.

Comaroff, J.L., Comaroff, J. and ProQuest (Firm) (2009) Ethnicity, Inc., Chicago: University of Chicago Press.

Dabène, O. (2019) Street Art and Democracy in Latin America, Cham: Palgrave Macmillan.

Damisch, H. (1972) Théorie du Nuage: pour une Histoire de la Peinture, Paris: Éditions du Seuil.

De Certeau, M. (1986) Heterologies: Discourse on the Other, Minneapolis: University of Minnesota Press.

De Parres Gómez, F. (2017) ‘Prácticas artísticas de resistencia simbólica: El Arte Callejero como estéticas de la ruptura en el espacio urbano moderno', in Patricia Gómez Rey and Fabián González Luna (eds) Miradas múltiples a la ciudad: fenómenos y problemáticas, 201-236, Mexico City: UNAM Ediciones Eon.

de Sousa Santos, B. (2014) Epistemologies of the South: Justice Against Epistemicide, London: Routledge.

(2018) The End of the Cognitive Empire: The Coming of Age of Epistemologies of the South, Durham, NC and London: Duke University Press.

Duncan, C. (1991) 'Art Museums and the Ritual of Citizenship', in Ivan Karp and Steven Lavine (eds) Exhibiting Culture: The Poetics and Politics of Museum Display, 88103, Washington DC: Smithsonian Institution Press.

Estévez González, F. (ed) (2004) El pasado en el presente, Santa Cruz de Tenerife: Gráficas Sabater.

(2019) Souvenir, souvenir, Un antropólogo ante el turismo, Valencia: Concreta.

Fabian, J. (1983) Time and the Other: How Anthropology Makes its Object, New York: Columbia University Press.

Ferris, N., Harrison, R. and Wilcox, M.V. (2014) Rethinking Colonial Pasts through Archaeology, Oxford: Oxford University Press.

Fouseki, K. (2010) 'Community Voices, Curatorial Choices': Community Consultation for the 1807 Exhibitions', Museum and Society 8 (3) 180-92.

Funari P., Zarankin, A. and Salerno, M.A. (eds) (2009) Memories from Darkness: Archaeology of Repression and Resistance in Latin America, New York/London: Springer.

García Canclini, N. (1990) Culturas Híbridas: Estrategias para entrar y salir de la modernidad, Mexico: Grijalbo.

Geismar, H. (2015) 'The Art of Anthropology: Questioning Contemporary Art in Ethnographic Display', in Andrea Witcomb and Kylie Message (eds) The International Handbook of Museum Studies: Museum Theory, 183-210, Chichester: Wiley Blackwell.

Gell, A. (1998) Art and Agency: An Anthropological Theory, Oxford: Oxford University Press. 
Gnecco, C. and Hernández, C. (2010) 'La historia y sus descontentos: estatuas de piedra, historias nativas y arqueólogos', in Cristóbal Gnecco and Patricia A Rocabado (eds) Pueblos indígenas y arqueología en América Latina, 85-136, Bogota: Fundación de Investigaciones Arqueológicas Nacionales, Banco de la Republica y CESO facultad de ciencias sociales, Universidad de los Andes.

Gnecco, C. and Rocabado, P.A. (eds) (2010) Pueblos indígenas y arqueología en América Latina, Bogota: Fundación de Investigaciones Arqueológicas Nacionales, Banco de la Republica y CESO facultad de ciencias sociales, Universidad de los Andes.

Gonseth, M.O., Hainard, J. and Kaehr, R. (eds) (2005) Cent ans d'éthnographie sur la colline de Saint Nicolas 1904-2004 [100 Years of Ethnography on the Hill of Saint Nicholas 1904-1910], Neuchâtel: Musée d'éthnographie.

González, O. (2010) Unveiling Secrets of War in the Peruvian Andes, Chicago: University of Chicago Press.

Graves-Brown, P., Harrison, R. and Piccini, A. (eds) (2013) The Oxford Handbook of the Archaeology of the Contemporary World, Oxford/New York: Oxford University Press.

Guzmán Carcaño, J.G. (1993) 'El carnaval de Huejotzingo: Espejo de la historia, vida y alma de un pueblo', Tramoya 35 39-46.

Harrison, F.V. (ed) (1991) Decolonizing Anthropology: Moving Further Toward an Anthropology for Liberation, Washington, DC: American Anthropological Association.

Harrison, R. and Breithoff, E. (2017) 'Archaeologies of the Contemporary World', Annual Review of Anthropology, 46 203-21.

Heidegger, M. (1927 [2008]) Being and Time, New York: Harper Collins.

Henriques, J. and Morley, D. with Goblot, V. (eds) (2017) Stuart Hall: Conversations, Projects and Legacies, London: Goldsmiths Press.

Henríquez, M. and de Santa Ana, M. (2019) (eds) 'Museotapías' Fernando Estévez, Las Palmas: César Manrique Foundation.

Hicks, D. (2020) The Brutish Museums, London: Pluto Press.

Hodder, I. (1985) 'Postprocessual Archaeology', in Michael B. Schiffer (ed) Advances in Archaeological Method and Theory 8 1-26.

(1987) 'The Contextual Analysis of Symbolic Meaning', in lan Hodder (ed) The Archaeology of Contextual Meanings, 1-10, Cambridge: Cambridge University Press.

Hodder, I., Shanks, M., Alexandri, A., Buchli, V., Carman, J., Last, J. and Lucas, G. (1995) Interpreting Archaeology: Finding Meaning in the Past, London and New York: Routledge.

Houston, S. (2014) The Life Within: Classic Maya and the Matter of Permanence, New Haven: Yale University Press.

Husserl, E. (1931 [1960]) Cartesian Meditations: An Introduction to Phenomenology, Dorion Cairns (trans) Dordrecht: Kluwer Academic Publishers.

Hymes, D.H. (1974) Reinventing Anthropology, New York: Vintage Books. 
Isaac, G. (2007) Mediating Knowledges: Origins of a Zuni Tribal Museum, Tucson: University of Arizona Press.

Isaac, G., Marsh, D.E., Osorio Sunnucks, L. and Shelton, A. (2019) ‘Borders and Interruptions: Museums in the Age of Global Mobility, Mexico City, 7-9 June 2017', Museum Worlds 71.

Janes, R.R. and Sandell, R. (2019) Museum Activism, London and New York: Routledge.

Jansen, M.E.R.G.N. and Pérez Jiménez, G.A. (2017) Time and the Ancestors: Aztec and Mixtec Ritual Art, Leiden: Brill.

Joyce, R. and Gillespie, S.D. (2015) Things in Motion: Object Itineraries in Anthropological Practice, Santa Fe, NM: School for Advanced Research Press.

Knell, S.J., MacLeod, S. and Watson, S. (eds) (2007) Museum Revolutions: How Museums Change and are Changed, London and New York: Routledge.

Latour, B. (2005) Reassembling the Social: An Introduction to Actor-Network-Theory, Oxford: Clarendon.

Lowenthal, D. (1985 [2015]) The Past is a Foreign Country, Cambridge: Cambridge University Press.

Lyotard, J.F. (1979) La Condition Postmoderne: Rapport Sur le Savoir, Paris: Les Editions de Minuit.

McAnany, P. (2016) Maya Cultural Heritage: How Archaeologists and Indigenous Communities Engage the Past, Lanham MD: Rowman and Littlefield.

Macdonald, S. and Basu, P. (2007) Exhibition Experiments, Malden, MA: Blackwell.

Macdonald, S. and Morgan, J. (2018) 'What Not to Collect? Post-connoisseurial Dystopia and the Profusion of Things', in Phillip Schorch and Conal McCarthy (eds) Curatopia: Museums and the Future of Curatorship, 29-43, Manchester: Manchester University Press.

McEnroe, S.F. (2012) From Colony to Nationhood in Mexico: Laying the Foundations, 1560-1840, Cambridge/New York: Cambridge University Press.

Meyer, B. (2009) Aesthetic Formations: Media, Religion, and the Senses, New York: Palgrave Macmillan.

Mignolo, W.D. and Walsh, C.E. (2018) On Decoloniality: Concepts, Analytics, Praxis, Durham, NC: Duke University Press.

Morgan, D. (2012) The Embodied Eye: Religious Visual Culture and the Social Life of Feeling, California: University of California Press.

Morphy, H. (2007) Becoming Art: Exploring Cross-Cultural Categories, Oxford: Berg Publishers.

Muratorio, B. (2000) 'Etnografía e historia visual de una etnicidad emergente: El caso de las pinturas de Tigua', in Fernando Carrión (ed) Desarollo cultural y gestión en centros históricos, 47-74, Quito: FLACSO.

Osorio Sunnucks, L., Isaac, G., and Marsh, D.E. (2018) ‘Documents of Dissent', in Philippe Tortell, Mark Turin and Margot Young (eds) Memory, 155-63, Vancouver: Peter Wall Institute for Advanced Studies. 
Peers, L.L. and Brown, A.K. (eds) (2003) Museums and Source Communities: A Routledge Reader, New York: Routledge.

Perera, V. and Bruce, R.D. (1985) The Last Lords of Palenque: The Lacandon Mayas of the Mexican Rain Forest, Berkeley: University of California Press.

Pérez Ruiz, M.L. (2008). 'La museología participativa: ¿tercera vertiente de la museología mexicana?', Cuicuilco, 44 87-110.

Phillips, R.B. (2011) Museum Pieces: Toward the Indigenization of Canadian Museums, Montreal: McGill-Queen's University Press.

Power, K. and Escobar, T. (2012) Palabras y poros en la piel, Asunción: Pisueña Press and Centro de Artes Visuales/Museo del Barro.

Procter, A. (2020) The Whole Picture: The Colonial Story of the Art in our Museums and Why We Need to Talk About It, London: Cassell.

Reilly, M. (2018) Curatorial Activism: Towards an Ethics of Curating, London: Thames and Hudson.

Reyes Gómez, J.C. (2017) Tiempo, cosmos y religión del pueblo Ayuuk (México), Leiden: Leiden University Press.

Ribeiro, G.L. (2014) 'World Anthropologies: Anthropological Cosmopolitanisms and Cosmopolitics', Annual Review of Anthropology, 43 483-98 doi:10.1146/annurevanthro-102313-030139.

Ribeiro, G. L. and Escobar, A. (2006) World Anthropologies: Disciplinary Transformations within Systems of Power, Oxford: Berg.

Rosenzweig, M.L. (2020) 'Confronting the Present: Archaeology in 2019', American Anthropologist, 122 (2) 284-305 doi:10.1111/aman.13411.

Sánchez Balderas, F. (2005) 'Arte rupestre de Metzabok: Una descripción preliminar', Bolom, Revista del Centro de Investigaciones Frans Blom 2 67-97.

Shanks, M. and Tilley, C. (1992) Reconstructing Archaeology: Theory and Practice, London: Routledge.

Shelton, A. (1997) 'The Future of Museum Ethnography,' Journal of Museum Ethnography, 9: 33-48.

(2000) 'Curating African Worlds', Journal of Museum Ethnography, 12: 5-20.

(2001) 'Museums in an Age of Cultural Hybridity', Folk: Journal of the Danish Ethnographic Society, 43 221-49.

(2013) 'Critical Museology: A Manifesto', Museum Worlds, 1 (1) 7-23 doi:10.3167/ armw.2013.010102.

(2018) 'Baroque Modernity: Critique and Indigenous Epistemologies in Museum Representations of the Andes and Amazonia', in Phillip Schorch and Conal McCarthy (eds) Curatopia: Museums and the Future of Curatorship, 124-42, Manchester: Manchester University Press.

Snoep, N. (2020) 'De la conServation à la conVersation: Le pari de la carte blanche', Multitudes, 78 (1) 198-202 doi:10.3917/mult.078.0198. 
Strathern, M. (1988) The Gender of the Gift: Problems with Women and Problems with Society in Melanesia, California: University of California Press.

Tilley, C. (1990) Reading Material Culture: Structuralism, Hermeneutics and PostStructuralism, Oxford: Basil Blackwell.

(2004) The Materiality of Stone: Explorations in Landscape Phenomenology, London: Bloomsbury Academic.

Tuhiwai Smith, L. (1999) Decolonising Methodologies: Research and Indigenous Peoples, London/New York: Zed Books.

Valiñas López, F.M. (2008) 'Los pintores de la tierra del condor: El arte de Tigua, Ecuador,' Cuadernos de arte de la Universidad de Granada, Norteamérica, 39, 233-50 https://revistaseug.ugr.es/index.php/caug/article/view/299.

Van Alphen, E. (2005) Art in Mind: How Contemporary Images Shape Thought, Chicago: University of Chicago Press.

Villanueva, N.B.V. (2014) 'La concepción de los aluxes según niños de ascendencia Maya', Temas Antropológicos, Revista Científica de Investigaciones Regionales, 36 (2) 97-125.

Vogel, S. (1991) Art/Artifact: African Art in Anthropology Collections, New York: Center for African Art.

Vonnegut, K. (1997) Timequake, New York: G. P. Putnam's Sons.

Wallis, B. (1994) 'Selling Nations: International Exhibitions and Cultural Diplomacy', in Daniel J. Sherman and Irit Rogoff (eds) Museum Culture: Histories, Discourses, Spectacles, 265-7, London: Routledge.

Ward, T. (2018) The Formation of Latin American Nations: From Late Antiquity to Early Modernity, Oklahoma: University of Oklahoma Press.

Xiu Cachón, G.A. (1993) Los aluxes: Duendes del Mayab (Testimonios reales de su existencia), Yucatan: Talleres Gráficos del Sudeste.

Ybarra-Frausto, T. (1991) 'The Chicano Movement/The Movement of Chicano Art', in Ivan Karp and Steven Lavine (eds) Exhibiting Culture: The Poetics and Politics of Museum Display, 128-50, Washington DC: Smithsonian Institution Press.

Yoshida, K. and Mack, J. (1997) (eds) Images of Other Cultures: Reviewing Ethnographic Collections of the British Museum and the National Museum of Ethnology, Osaka: NHK Service Centre.

\section{Author}

Laura Osorio Sunnucks

British Museum

United Kingdom

\section{lauraannosorio@gmail.com}

\section{Bio Statement}

Head of the Santo Domingo Centre of Excellence for Latin American Research British Museum, AOA 